\title{
A MODEL OF NUTRITION INFORMATION SEARCH WITH AN APPLICATION TO FOOD LABELS
}

\author{
Andreas C Drichoutis ${ }^{1}$, Panagiotis Lazaridis ${ }^{2}$ and Rodolfo M. Nayga, $\mathrm{Jr}^{3}$
}

\author{
${ }^{1}$ Dept. of Agricultural Economics and Rural Development \\ Agricultural University of Athens \\ Iera Odos 75, 11855 \\ Athens, Greece \\ Email: adrihout@aua.gr \\ ${ }^{2}$ Dept. of Agricultural Economics and Rural Development \\ Agricultural University of Athens \\ Iera Odos 75, 11855 \\ Athens, Greece \\ Email: t.lazaridis@aua.gr \\ ${ }^{3}$ Dept. of Agricultural Economics and Agribusiness \\ University of Arkansas \\ Fayetteville, AR 72701 \\ USA \\ Email: rnayga@uark.edu
}

\begin{abstract}
Due to the dramatic rise of several diet-related chronic diseases, nutrition information search behaviours have received significant interest from both the scientific and nonscientific literature. No other known paper in economics, however, has examined from a theoretical perspective the acquisition of nutrition information as a health enhancing activity. We modify the standard health capital model (Grossman, 1972) to allow the time spent on nutrition information search to be considered within the context of a time allocation decision. We then collected extensive primary data based on the theoretical model and used these to test the model.
\end{abstract}




\title{
A MODEL OF NUTRITION INFORMATION SEARCH WITH AN APPLICATION TO FOOD LABELS
}

\begin{abstract}
Due to the dramatic rise of several diet-related chronic diseases, nutrition information search behaviours have received significant interest from both the scientific and nonscientific literature. No other known paper in economics, however, has examined from a theoretical perspective the acquisition of nutrition information as a health enhancing activity. We modify the standard health capital model (Grossman, 1972) to allow the time spent on nutrition information search to be considered within the context of a time allocation decision. We then collected extensive primary data based on the theoretical model and used these to test the model.
\end{abstract}

\section{INTRODUCTION}

Information search behaviours have long been a subject of interest for economists (e.g. Stigler, 1961). Due to the dramatic rise of several diet-related chronic diseases, nutrition information search behaviours have also received significant attention lately from both the scientific and non-scientific literature. The rise of food related diseases, caused among others by obesity, have been dramatic. WHO indicated that in 2005 there were 1.6 billion overweight adults and at least 400 million obese adults in the world (2006). By 2015, these figures are expected to rise to 2.3 billion overweight and 700 million obese adults. Some of the key causes of this epidemic are increased consumption of energydense foods high in saturated fats and sugars and reduced physical activity.

Researchers are constantly looking for ways to explain and/or tackle the problem of poor diets. It is possible that the reason people do not follow adequate diets is that they do not know the proper foods to consume. Hence, people who are motivated to change their diet may engage in search and acquisition of nutrition information. One of the major sources of nutrition information hypothesized to help consumers make healthier food choices is on-pack nutrition information on food products, also known as nutritional label (Nayga, 1996). Nutritional labels however are not the only source of nutrition information. TV, radio, newspapers, medical experts or even family and friends can be sources of nutrition information. However, the literature suggests that as much as two thirds of final purchase decisions are made in stores while shopping (Caswell and Padberg, 1992), which then reduces the influential role of other external sources of information on food choice. This may be the reason why a number of studies have focused on on-pack nutrition information of food products. For example, Guthrie et al. (1995), Kim et al. (2001) and Nayga (1996, 2000) empirically investigate the factors that affect nutritional food label use. All these applications have explored nutrition information search behaviour from an empirical perspective

On the other hand, many disciplines have been using theories to explain health related behaviour and several conceptual models have been produced (Backman, et al., 2002, Bissonnette and Contento, 2001, Furst, et al., 1996, Rosenkranz and Dzewaltowski, 2008, van der Horst, et al., 2007). For example, psychological based theories like the Health Belief Model (Becker, 1974), Protection Motivation Theory (Maddux and Rogers, 
1983), the Theory of Reasoned Action (Ajzen and Fishbein, 1980), and Social Cognitive Theory (Bandura, 1986) have dominated the respective literature. In sociology, Role theory (Cohen and Williamson, 1991, Lin and Ensel, 1989), Structural theories(Dahlgren and Whitehead, 1991), cultural approaches (Fischler, 1988, Murcott, 1998), theories of class and lifestyles (Sobal, 2004) and constructivist theories (Tomlinson, 2003) are employed for health related behaviour.

The utility maximization theory is the hand tool of mainstream economics. Along with this theory, Grossman (1972) developed a model for the demand of health and has inspired much of the literature in the field of health economics. In this paper, we modify the standard health capital model of Grossman by allowing individuals to select the time they want to spend on searching for nutrition information. Up to know, no other known study to us, has developed a theoretical economic model of nutritional information search and acquisition, although the empirical mechanisms of nutritional information search have been addressed in the book edited by Chern and Rickertsen (Chern and Rickertsen, 2003). In this paper, we use a utility theoretic approach, to examine nutrition information acquisition as part of the health investment problem. We show that our simple theoretical model introduces new perspectives on nutrition information search behaviour that the empirical literature has neglected, probably because they are not completely self-evident. In developing the theoretical model, we consider nutrition information acquisition to be a health enhancing activity, similar to the health capital concept introduced by Grossman in his seminal paper (Grossman, 1972). In Grossman's model of the demand for health, health is a capital good produced via time and money and thus determines the amount of time available for market and non-market activities and the amount of income available to purchase non-health goods. Within the context of Becker's household production function framework (Becker, 1965), health was treated as a durable item. Thus, individuals inherit an initial stock of health capital that depreciates with age and can be increased by investment. Net investment in the stock of health equals gross investment minus depreciation. Direct investments in health include the own time of the consumer, medical care, diet, exercise, recreation etc.

The next section of the paper focuses on the development of the theoretical model in which we develop a model of nutrition information acquisition. We then use comparative statics to make theoretical predictions of what may happen when we change some of the key variables of the model. We then provide an empirical application using data from a large-scale survey conducted in Athens, Greece.

\section{THE THEORETICAL MODEL}

We assume that there are three composite commodities in the market. The first group of commodities, which we treat as a single product, is an 'unhealthy' food product which we denote as $B$, while the other group includes 'healthy' foods that we denote as $G$. The third group, denoted as $Z$, includes all other commodities. As consumption commodities, the quantities of the two foods $G$ and $B$ and the quantity of $Z$ enter the utility function directly. Consumers also get utility from the health stock $H$ they possess and from other time components. Let the utility function of a typical consumer be:

$U=U\left(H, G, B, Z, W, E, N, R ; S_{1}\right)$

which is quasi-concave and twice differentiable. $S_{1}$ is a vector of demographic variables and other demand shifters, $W$ is working time, $E$ is time spent on health 
enhancing activities (e.g. sports or exercise time in general), $N$ is time spent on searching and acquiring nutrition information and $R$ is residual time. $U$ has the following property: $U=U\left(H, 0,0, Z, W, E, N, R ; S_{1}\right)=0$, which suggests that food is essential for the individual. Consumption of goods is such that $U_{G}>0, U_{B}>0$ and $U_{Z}>0$. The direct positive effect of the three goods in the utility signifies that these products can provide a pleasurable consumption experience. However, $U_{G G}<0, U_{B B}<0$ and $U_{Z Z}<0$ because each added unit of the goods will produce less consumption pleasure. Ditto, we assume that $U_{H}>0$ and $U_{H H}<0$. In addition, following, Becker (1965), DeSerpa (1971) and Evans (1972), we include time components as specific arguments in the utility function. Consumers produce health according to the health production function:

$H=H\left(G, B, W, E, N i ; S_{2}, \delta, k, n\right)$

We define as $N i$ the stock of nutrition information possessed by the individual where $H_{N i}>0$. Of course, other market goods, such as medical care, are also inputs in the production of health. We choose to ignore these in order to emphasize the aspect of diet on health, which is a key concept for this study. We consider nutrition information stock as a human capital variable since as Becker (2002) points out, "human capital refers to the knowledge, information, ideas, skills, and health of individuals" (our italics). In this context, nutrition information stock can improve health ceteris paribus as in Grossman's (1972) health capital model where the stock of human capital is considered an exogenous variable that influences investment in health. Therefore, nutrition information can affect health through productive efficiency.

We also assume that:

$G=G\left(N i ; t, S_{3}\right)$

and

$B=B\left(N i ; t, S_{3}\right)$

Equations (3) and (4) indicate that nutrition information stock can affect the quantities of the foods and therefore the health equation (2). Therefore nutrition information can also affect health through allocative efficiency. $t$ represents taste preferences. What equations (3) and (4) depict is choice of foods based on taste and nutrition which represent the two major drivers of consumption.

We also assume that the nutrition information stock is endogenous and produced according to the production function,

$\mathrm{Ni}=\mathrm{Ni}\left(\mathrm{mN} ; \mathrm{N}_{\mathrm{k}}, \mathrm{S}_{4}\right)$

The consumer can invest in his/her stock of nutrition information by searching and acquiring nutritional information and this investment is facilitated by nutrition knowledge $N_{k}$. Equation (5)shows that the consumer can invest in the amount of nutritional information he/she possesses by acquiring new information (or equivalently by refreshing his/her knowledge). $m$ reflects the efficiency of the consumer to derive and process information from one unit of time $N$ that he/she spends gathering information $(0 \leq m \leq 1)$. Equivalently, the $m$ variable also captures disinformation or lack of information. For example, a consumer that faces confusing information or is struggling to find information that is not available, will have low efficiency values. If $m=1$ then all the time he/she allocates on nutrition information search is contributing to enhancing the nutrition information stock. The $m$ variable can be considered a human capital variable 
that is fixed in the short run. Note that it is perfectly fine for an agent not to spend time in searching for nutrition information, that is $N=0$. From equation (5), this would mean that nutrition information stock is formatted by some general nutrition knowledge. In the extreme case where an individual is neither spending time to search for nutrition information $(N=0)$ nor has some general nutrition knowledge $\left(N_{k}=0\right)$, it can be that $N i=0$. Therefore, according to equations (3) and (4) the agent will be deciding on his food choices based solely on his taste preferences $t$. In any other case, where the agent has some positive nutrition information stock, equations (3) and (4) imply a taste-nutrition trade-off taking place in the food decision process.

At this point, it would be useful to elaborate on the conceptualization of knowledge about nutrition in our study. We conceptualize two distinct forms of knowledge about nutrition. The first form is knowledge of general principles about nutrition $N_{k}$ (e.g. awareness of experts' advice or dietary recommendations). The second form is the specific knowledge about the nutrient content of foods $\mathrm{Ni}$ (e.g., if a food is low/high in a nutrient or which of a pair of foods has more/less of a nutrient). One would expect an endogenous relation of nutrition knowledge with nutrition information acquisition (i.e. higher nutrition knowledge) may affect the likelihood of searching for nutrition information. However, searching for nutrition information may also affect nutrition knowledge. The empirical measures of nutrition knowledge used in past studies are a combination of what we conceptualize as general knowledge and specific knowledge. The endogeneity issue could be a result of the failure to recognize the distinct forms of nutrition knowledge. In our model, we assume that general knowledge can affect information search behaviour (since it may facilitate comprehension of nutrient information) but not the other way around i.e. increased nutrition information search will not provide the individual with more information about general principles of nutrition. However, we recognize that increased nutrition information search can and will affect the specific nutrition knowledge $\mathrm{Ni}$. Note that this distinction of nutrition knowledge has also been made by Blaylock et al. (1999).

In the health production function (2), $G$ and $B$ are inputs in the production of health. The assumption of foods that can either increase or decrease the level of health is commonly being used when trying to model healthy and unhealthy consumption (e.g. Forster, 2001). While from a nutritionist's perspective this would seem as an oversimplification, it is hard to think of a model where the complex puzzle of nutrition is taken into account while managing to keep the model tractable. The good food-bad food dichotomy can serve and has served as a good proxy in theoretical applications of nutrition.

Note that the two food products $G$ and $B$ appear directly in the utility function (1) and indirectly through the health stock production function (2) implying that there are two different mechanisms in which food affects utility, which in turn suggests that food plays a twofold role for the consumer. The first role is achieved through taste since $G$ and $B$ can provide a pleasurable consumption experience, thereby increasing utility. The second role is the fulfilment of energy and nutritional requirements (or equivalently the avoidance of intake of certain nutrients beyond a certain level), which are achieved through the health production function (2).

$E$ and $W$ are time inputs in the health production that directly affect the level of health. Working time $W$ is also assumed to affect the level of health stock either positively or negatively: positively due to healthy components of work (e.g., physical 
activity on job) or negatively due to unhealthy components of work (e.g., job strain). The $k$ and $n$ variables capture the healthy and unhealthy components of work (e.g., strain, physical activity or satisfaction at/from work) assuming that they affect the efficiency of the production process of health. Such factors are well known to affect health (Ganster and Schaubroeck, 1991, Haskell, 1995, Wilkins and Beaudet, 1998). As in Grossman's paper (Grossman, 1972), $\delta$ is the rate of depreciation of health which is assumed to be exogenous and vary with the age of the individual or environmental conditions. $S_{2}$ is the stock of human capital which refers to the knowledge, information, ideas, skills and health of individuals (Becker, 2002). Ni can also be seen as a human capital variable, which refers to knowledge that can make an individual a more efficient producer of health.

From an individual's point of view, both market goods and own time are scarce resources. We assume that the consumers' market wage rate is $w$ and $Y$ is unearned income. The goods budget constraint equates the value of outlays on goods to income, under the assumption that the consumer does not save:

$P_{G} G+P_{B} B+P_{z} Z=w W+Y$

Here $P_{G}, P_{B}$ and $P_{Z}$ are the prices of $G, B$ and $Z$, respectively. Similarly, the individual faces a binding time constraint and can choose on the time he/she will spend on the different activities in order to exhaust a time endowment equal to $T$, where $T$ equals the length of the decision period (e.g., twenty four hours for a period of one day): $W+E+N+R=T$

\subsection{EQUILIBRIUM CONDITIONS}

The equilibrium conditions can now be found by maximizing the utility function (1) subject to the constraints given by equations (2) to (7). Since all the constraints can be substituted in the utility function, this can turn into an unconstrained maximization problem. However, there is a scope to use constrained maximization since the Lagrange multiplier can have useful interpretations. Equations (2) to (5) can be substituted in the utility function (1) and one can solve the maximization problem which will result to explicit choice functions for $W, E, N, R, Z, \lambda_{1}$ and $\lambda_{2}$, which are specified as functions of a vector of variables $v$ where $v=m, \delta, t, P_{G}, P_{B}, P_{Z}, w, Y, T, S_{1}, S_{2}, S_{3}, S_{4}, N_{K}, n, k$. Putting the optimal solutions back into the health outcome production function (2), the food functions (3) and (4) and the nutrition information production function (5), we also get the following functions:

$$
\begin{aligned}
& H=H\left(G\left(N i\left(m N^{*}\right)\right), B\left(N i\left(m N^{*}\right)\right), W, E, N i\left(m N^{*}\right) ; S_{2}, \delta, k, n\right) \\
& G=G\left(N i\left(m N^{*}\right) ; t, S_{3}\right) \\
& B=B\left(N i\left(m N^{*}\right) ; t, S_{3}\right)
\end{aligned}
$$

and

$$
\mathrm{Ni}=\mathrm{Ni}\left(\mathrm{mN}^{*} ; \mathrm{N}_{k}, \mathrm{~S}_{4}\right)
$$

The derivation of the FOC's by construction restricts the model to interior solutions. However, the model could easily be modified to allow for corner solutions. Most interesting would be a corner solution for time spent in searching and acquiring nutrition information. Then one of the FOCs should be modified from $L_{N}=0$ to $L_{N}<0$ 
which results into

$U_{N}+m U_{H} N i_{m N}\left(H_{N i}+H_{G} G_{N i}+H_{B} B_{N i}\right)-\left(U_{Z} / P_{Z}\right) m N i_{m N}\left(P_{G} G_{N i}+P_{B} B_{N i}\right)<\lambda_{2}$. That is the marginal utility of nutrition information search time is less than the marginal cost of time and therefore the consumer will choose $N=0$. The corner solution indicates that if the marginal benefit of nutrition information search [through investments in health $\left(m U_{H} N i_{m N}\left(H_{N i}+H_{G} G_{N i}+H_{B} B_{N i}\right)\right)$ and as a direct source of utility $\left(U_{N}\right)$ minus the monetary consequences of food choices $\left.\left(U_{Z} / P_{Z}\right) m N i_{m N}\left(P_{G} G_{N i}+P_{B} B_{N i}\right)\right]$ is less than the marginal cost of time $\lambda_{2}$ then the consumer will choose not to spend any time searching for nutrition information.

The Lagrangian multipliers $\lambda_{1}$ and $\lambda_{2}$, are shadow variables representing the marginal utility of money and the marginal utility of time, respectively. The ratio of the multipliers $\lambda_{2} / \lambda_{1}$ commonly labeled the 'resource value of time' or the 'shadow price of time’ (Collings, 1974, De Donnea, 1972, DeSerpa, 1971, Heckman, 1974) can be expressed as:

$$
\begin{aligned}
& \frac{\lambda_{2}}{\lambda_{1}}=\frac{U_{W}+U_{H} H_{W}}{\lambda_{1}}-w=\frac{U_{E}+U_{H} H_{E}}{\lambda_{1}}= \\
& =\frac{U_{N}+m U_{H} N i_{m N}\left(H_{N i}+H_{G} G_{N i}+H_{B} B_{N i}\right)}{\lambda_{1}}- \\
& -m N i_{m N}\left(P_{G} G_{N i}+P_{B} B_{N i}\right)
\end{aligned}
$$

These last equalities describe the monetary value the individual places on the marginal units of time. If this monetary value on the marginal units of time exceeds the marginal utility of nutrition information search, the consumer will choose not to spend time searching and acquiring nutrition information.

\section{COMPARATIVE STATICS}

We use the derived demand equations from the model above to guide our empirical application and to test the model. Due to the number of choice variables in the theoretical model and in order to derive refutable hypotheses, we conduct comparative statics analysis on a simpler model than the one discussed above. At this level of generality no refutable propositions will be forthcoming. In the simpler model, we reduce the number of choice variables but keep the variables of interest. Therefore, we assume that the individual has decided on the consumption level of the $Z$ commodity on a previous stage of the decision process along with the money he/she will allocate on buying the food commodities. We also dismiss the allocation decision on working time and exercise time and assume for simplicity that the individual is deciding only on whether to spend time searching for nutrition information. Assuming the utility function for food is separable from the $Z$ commodity we let the utility function of an individual be:

$V=V\left(H, G, B, N, R ; S_{1}\right)$

Subject to:

$P_{G} G+P_{B} B=I$

$N+R=T$

and equations (3), (4) and (5). 
For the derivation of comparative statics, we use a primal-dual analysis (Silberberg and Suen, 2001). See also Silberberg (1974) for more generalized results. The primal dual method offers an alternative and simpler method of comparative statics than Samuelson (1947).

In brief this procedure involves defining the dual problem of utility maximization by substituting the optimal values of the choice variables back into the utility function. A second maximization of the indirect utility function follows and the fundamental comparative statics equation is based on the sufficient second order conditions of the dual problem. Unfortunately no refutable implications are forthcoming for parameters that enter either the budget or time constraint (see Silberberg and Suen, 2001). The only parameter that can have useful interpretations is the depreciation rate of health $\delta$. This variable can have some useful interpretations by assuming that it is positively associated with age (Grossman, 1972).

The fundamental comparative statics equation for $\delta$ is ${ }^{1}$ :

$\left(V_{N H} H_{\delta}\right) N_{\delta}<0$

Assuming that $V_{N H}<0$ and $H_{\delta}<0$ then $N_{\delta}<0$.

Proposition 1. Older consumers $(\delta)$ will spend less time searching for nutrition information $\left(N_{\delta}<0\right)$.

Under this proposition as individuals get older they will spend less time searching for nutrition information. The reasons could be greater market experience (Phillips and Sternthal, 1977) and/or slower information processing rate (John and Cole, 1986, Phillips and Sternthal, 1977, Wickens, et al., 1987).

\section{EMPIRICAL TESTING}

The empirical application of the theoretical model is focused on search for nutrition information from food labels. To test the model, we estimate demand functions from the full model as exposed in Section 2. While the shorter version of the model in Section 3 serves well for the comparative statics application, the full model provides more information for empirically testing the theoretical relations. In our empirical testing, we disregard labor time $(W)$ and exercise time $(E)$ as time allocation decisions, since this would require regressing these variables over a set of independent variables unrelated to this study. For the same reason, we disregard residual time $(R)$ and quantity of all other commodities (Z).

We therefore estimate the following system of equations:

$$
\begin{aligned}
& N=a_{0}+\mathbf{a}_{1} \mathbf{X}+\mathbf{a}_{2} \text { Work }+a_{3} \text { Nknow }+a_{4} \text { Effic }+a_{5} \text { Taste }+u_{1} \\
& N i=b_{0}+b_{1} N+\mathbf{b}_{2} \mathbf{X}+\mathbf{b}_{3} \text { ISources }+b_{4} N \text { Nnow }+b_{5} \text { Effic }+u_{2} \\
& G B=c_{0}+c_{1} N i+\mathbf{c}_{2} \mathbf{X}+c_{3} \text { Taste }+c_{4} \text { Smoke }+c_{5} \text { Planner }+u_{3} \\
& H=d_{0}+d_{1} G B+d_{2} N i+\mathbf{d}_{3} \mathbf{X}+\mathbf{d}_{4} \text { Work }+d_{5} \text { Exercise }+d_{6} \text { Smoke }+u_{4}
\end{aligned}
$$

Note that the above system of equations is identified (one can check by the order condition). The order condition of identifiability requires that the number of predetermined variables excluded from the equation must not be less than the number of endogenous variables included in that equation less 1 , that is: $K-k \geq m-1$, where $K$ is

\footnotetext{
${ }^{1}$ All derivations are available upon request.
} 
the number of predetermined variables in the model, $k$ is the number or predetermined variables in a given equation and $m$ is the number of endogenous variables in a given equation.

Equation (17) corresponds to the demand equation for time. Equations (18), (19) and (20) correspond to the production functions (8) to (11). The only difference is that instead of estimating two separate equations for the $G$ and $B$ foods, we combine these to a single equation. While it is useful in theoretical modeling to separate foods into healthy and unhealthy categories, in reality, from a nutritionist's perspective, it is hard to explicitly classify foods as healthy or unhealthy. We therefore approximate $G$ and $B$ foods with a diet quality index $G B$. Since our survey was conducted in a Mediterranean country a natural candidate is the Mediterranean diet index. Studies from the medical literature have long derived, used and validated such an index. We used the Mediterranean Diet Score index developed by Trichopoulou et al. (2003) (more details on the construction and validity of the index are given on a subsequent section).

We further assume that market prices for the survey period remain constant. Since it isn't easy to collect data on the respondent's market wage rate $w$, we use working time as a proxy for opportunity cost of time (You and Nayga, 2005). Furthermore, instead of the unearned income $Y$, we will use household's annual income $I$ as a proxy.

The $\mathbf{X}$ vector is a vector of variables including geographical location, gender, age, education, household size of the respondent and level of household income. The Work vector is vector of work related variables including weekly working hours, job flexibility, job strain and the demands of job in terms of physical exertion and walking. The

ISources vector is a vector of dummies indicating if the respondent uses other information sources to gather nutrition information such as the media, friends/family, medical advice etc. Other variables in the system (17)-(20) include nutrition knowledge, efficiency of reading nutrition labels, importance of taste in the food decision process, smoking and exercise behaviour and meal planner duties. Details on the measurement of the variables are given in a subsequent section.

\section{THE DATA}

In order to empirically test the theoretical model and since no available secondary data exist with respect to the variables we want to use, we conducted a consumer survey using personal interviews, from December 2005 to April 2006. The questionnaire developed was pre-tested to a small sample of consumers during November 2005. The survey covered the Athens city in Greece. A multistage stratified sampling method was used for the survey. In total, we selected 95 areas (consisting of one or more unified blocks) covering the entire city area. The systematic sample that was drawn from each area was then visited during the morning and afternoon hours and if a contact could not be established, a letter was distributed to them explaining the purpose of the survey and asking for their participation. If a household could not be located (e.g., if the household moved), it was replaced with another household when possible. The households were then revisited during the afternoon hours. A total of 2565 households were selected to participate in the survey. However, some households were not found (e.g., moved) thus reducing the initial sample to 2542 households. We were not able to establish contact with 1277 households and 899 households refused to cooperate yielding a response and cooperation rates of $14.40 \%$ and $28.93 \%$, respectively. Even though response rate seems 
low at first glance we should note that it was not possible to establish contact with a respectable number of households. Ideally we could have increased response rate by revisiting those households over and over until we get a definite 'yes' or 'no' regarding their willingness to participate in the survey. However, this would mean that each of the 95 areas would have to be revisited almost indefinitely, which was not possible considering the widespread area of Athens and the available means for the conduct of the survey. Therefore, it is more appropriate to look also at ratios such as the no-contact rate which was about $50.24 \%$. This means that we were not able to establish contact with more than half of our initial sample. The refusal rate was about $35.37 \%$. A total of 366 households agreed to participate in the survey.

When the household agreed to participate in the survey, we asked to interview the major food shopper (in order to be able to answer the label use questions and be familiar with the food choice process) or we randomly chose one of the household shoppers if more than one individuals did the grocery shopping. Individuals who failed to respond to a question or to report their socioeconomic and demographic information were dropped from the sample. Hence, the number of respondents used in the analysis was 356. Table 1 compares the key demographics of the respondents and the overall synthesis of their households with that of the 2001 census of Athens. Since we interviewed the major grocery shoppers, we did not expect the percentages of gender and age categories of the interviewees to be close to that of the 2001 census (surveyed sample row). However, we also collected information on the gender and age of the other members of the household. The demographic profile of the households that participated in the survey (using information for all the members of the household) compares well with the 2001 census (household synthesis row).

Table 1. Demographic characteristics by gender and age

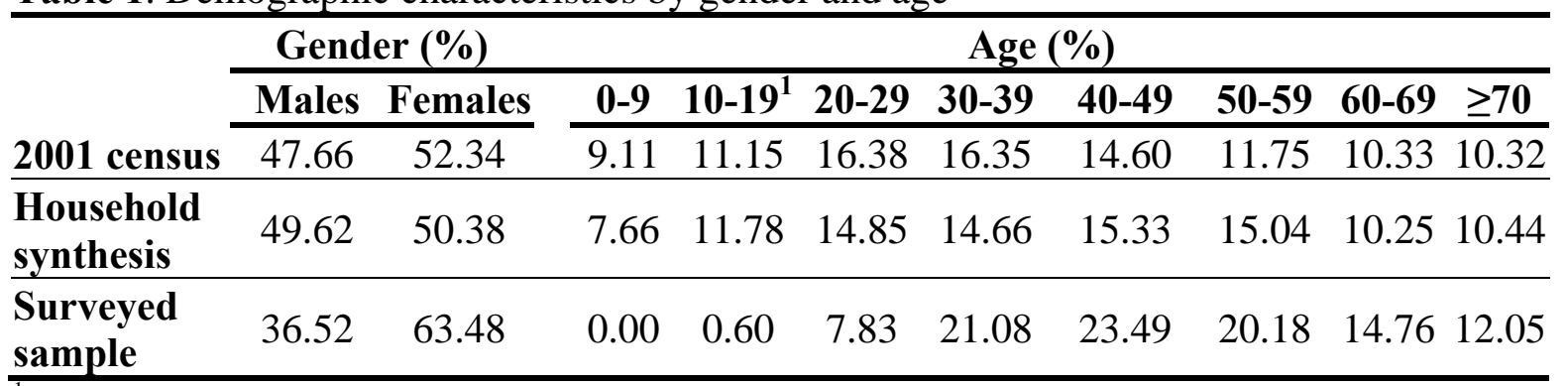

${ }^{1}$ The survey was addressed to the major grocery shoppers who in all cases were above 18 years old. Therefore the row labelled 'surveyed sample' includes only few cases for the age category of 10-19 years old.

\section{MEASUREMENT OF VARIABLES}

\subsection{MEASUREMENT OF DEPENDENT VARIABLES}

Time searching for nutrition information is proxied by time spent reading nutritional labels for food products. We find this a good proxy of overall nutrition information search behaviour since it usually takes place in a grocery shop setting where as much as two thirds of final purchase decisions are made (Caswell and Padberg, 1992).

To measure label use time $(N)$, we asked consumers to think about many food products that carry nutritional labels. To avoid confusion, each respondent was then 
showed a $11(\mathrm{~cm}) \times 7(\mathrm{~cm})$ nutritional label indicating that this is how a typical nutritional label looks like (details on the format of the label are described later). Following Drichoutis et al. (2005), Guthrie et al. (1995), Nayga (2000) and Szykman et al. (1997), we use a self-reported measure for label use. We therefore asked respondents to indicate how often they use nutritional labels when grocery shopping with possible answers ranging from never, not often, medium, often and always.

In our estimations we also used other measures of label use like frequency of reading labels while at home, frequency of reading labels when buying a food product for the first time, frequency of comparing nutritional labels between products and frequency with which nutritional labels affect purchase decision. Results are generally consistent across estimations.

To measure diet quality, we constructed a scale according to Trichopoulou et al. (2003) : we asked respondents to indicate how often they personally consume each of eleven food items/groups, chosen to represent the major food groups of the Mediterranean diet pyramid, on a six item scale. Possible answers were never, 1-2 times a month, 1-2 times a week, 3-4 times a week, once a day and more than once a day. A value of 0 or 1 was assigned to each of the eleven indicated components with the use of the sexspecific median as the cutoff. For beneficial components (fruit, grains, vegetables, fish, beans, nuts, pulses and olives), individuals with consumption below the median were assigned a 0 and persons with consumption at or above the median were assigned a 1 . For components presumed to be harmful (meat, poultry and dairy which are rarely low-fat or non-fat), persons whose consumption was below the median were assigned a value of 1 , and persons whose consumption was at or above the median were assigned a value of 0 . Thus, the total Mediterranean Diet Score $(G B)$ ranged from 0 (minimal adherence to the traditional Mediterranean diet) to 11 (maximal adherence). The average $G B$ is 6.08 and ranges from 1 to 11 for the surveyed sample. A question that might be raised at this point is whether self-reported frequency of consumption of specific food staples can accurately indicate if a person is on a Mediterranean diet or not. There are two arguments in support of the validity of the Mediterranean diet score. First, the components of the score that were derived from a semi-quantitative food frequency questionnaire have been validated in an ad hoc investigation (Gnardellis, et al., 1995). Second, in a large study, that was published in a major medical journal (Trichopoulou, et al., 2003), the Mediterranean diet score was found to strongly predict subsequent mortality. A limitation of the index could be that the way it is formed, it indicates relative diet quality rather than absolute diet quality because it compares each individual's consumption with the median consumption. The assumption is that median consumption is representative of how much (or how frequently) people should eat specific foods to conform to the Mediterranean diet.

Nutrition information stock $(\mathrm{Ni})$ is measured as the knowledge of the specific nutrient content of foods. We used 7 questions of pairwise comparison of the nutrient content of foods (Blaylock, et al., 1999, Drichoutis, et al., 2005, Parmenter and Wardle, 1999). Consumers were asked to compare certain foods (e.g., butter vs. margarine, whole milk vs. skim milk, white bread vs. whole wheat bread etc) and were asked to indicate which has more cholesterol, fat, fibre, calories etc (see Table 2). The respondents were assigned a score of 1 for a correct answer and a score of 0 for an incorrect answer, thus yielding a score between 0 and 7 for each respondent $(\mathrm{Ni})$.

To measure stock of health $(H)$, similar to Grossman (1999) and Wagstaff (1993), we use individual's self-evaluation of their health status. Therefore, consumers were 
asked to rate their health status on a five point likert scale ranging from very bad health status to very good health status. Since few respondents reported their health as being bad or very bad, in the analysis we merged these categories with the medium health category.

Table 2. Names and Description of dependent variables

\begin{tabular}{|c|c|c|c|c|c|}
\hline Variable & Variable Description & Scale & $\mathbf{N}$ & Mean & S.D. \\
\hline \multirow{6}{*}{$N$} & $\begin{array}{l}\text { How often respondent uses nutritional } \\
\text { labels while grocery shopping }\end{array}$ & $0-4$ & & 2.595 & 1.441 \\
\hline & Always & & 121 & & \\
\hline & Often & & 68 & & \\
\hline & Medium & & 40 & & \\
\hline & Rarely & & 88 & & \\
\hline & Never & & 39 & & \\
\hline$G B$ & $\begin{array}{l}\text { Diet quality index (Mediterranean } \\
\text { Diet score) }\end{array}$ & $0-11$ & & 6.084 & 1.823 \\
\hline \multirow{8}{*}{$\mathrm{Ni}$} & Nutrition information stock & $0-7$ & & 4.567 & 1.226 \\
\hline & $\begin{array}{l}\text { Proteins/ Whole milk vs skimmed } \\
\text { milk }\end{array}$ & 0,1 & 126 & 0.354 & 0.479 \\
\hline & Calories/Butter vs margarine & 0,1 & 36 & 0.101 & 0.302 \\
\hline & $\begin{array}{l}\text { Vitamins/White vs whole wheat } \\
\text { bread }\end{array}$ & 0,1 & 294 & 0.826 & 0.380 \\
\hline & Fat/Yoghurt vs whipping cream & 0,1 & 331 & 0.930 & 0.256 \\
\hline & $\begin{array}{l}\text { Cholesterol/ Whole milk vs skimmed } \\
\text { milk }\end{array}$ & 0,1 & 283 & 0.795 & 0.404 \\
\hline & Fibre/White vs whole wheat bread & 0,1 & 304 & 0.854 & 0.354 \\
\hline & Cholesterol/Butter vs margarine & 0,1 & 252 & 0.708 & 0.455 \\
\hline \multirow{4}{*}{$H$} & Health stock & $0-2$ & & 1.699 & 0.737 \\
\hline & Very good & & 43 & & \\
\hline & Good & & 179 & & \\
\hline & Medium, Bad or very bad & & 134 & & \\
\hline
\end{tabular}

*The variables with an asterisk where omitted for estimation purposes

\subsection{MEASUREMENT OF INDEPENDENT VARIABLES}

To measure nutrition knowledge $\left(N_{k}\right)$, we asked a series of questions derived from the Nutrition Knowledge questionnaire (Parmenter and Wardle, 1999). The questions examined consumers' knowledge on four sections: dietary recommendations, sources of nutrients, choosing everyday foods and diet-disease relationships. These four sections were composed of nine questions. For example, we asked consumers to state which kind of fat should they cut down (saturated or monounsaturated), which foods mainly contain saturated fats (vegetables, dairy or both), if they agree or disagree that some foods contain a lot of fat but no cholesterol and if brown sugar is better dietary alternative than white sugar. Two more questions examined consumers ability to choose the healthiest food alternative (e.g. choose between beef stake, pork stake, sausages and turkey in terms of fat) and the last three questions tested consumers knowledge of diet-disease relation (consumers were asked if they agree or disagree that eating less saturated fat, more 
fruits/vegetables and less salt can help in fighting heart diseases). Correct answers were assigned a score of 1 while incorrect answers were assigned a score of 0 thus yielding a score between 0 and 9 for each respondent.

While some could expect some overlap of the nutrition knowledge variable with the nutrition information stock, a low correlation coefficient of 0.33 indicates otherwise. This further supports our intention to model these variables as separate theoretical constructs. Table 3, tabulates the means of specific and general nutrition knowledge and correlation coefficients by perceived health status of individuals. Both measures seem to increase with perceived health status. However, in terms of percentages, specific knowledge increases by more than $14.5 \%$ compared to $6.8 \%$ for general knowledge, when moving from medium or worse health status to very good health status. This suggests that there might be different patterns that explain these variables.

Table 3. Means and correlations coefficients for general and specific nutrition knowledge by health status

\begin{tabular}{lccc}
\cline { 2 - 4 } & \multicolumn{3}{c}{ Health } \\
& Medium or worse & Good & Very good \\
\hline $\begin{array}{l}\text { General knowledge } \\
\text { (NKnow) }\end{array}$ & 5.44 & 5.47 & 5.81 \\
Specific knowledge $(\mathrm{Ni})$ & 4.34 & & \\
Correlation coefficient & 0.36 & 4.64 & 4.98 \\
\hline
\end{tabular}

The healthy and unhealthy components of work $(n, k)$ were proxied by job strain, work flexibility, physical demands of work and the requirement of working or standing while at work. The type of occupational stress having a negative impact on workers' health is defined as job strain (Béjean and Sultan-Taïeb, 2005, Karasek, 1979, Karasek and Theorell, 1990). Job strain occurs when job demands are high and job decision latitude is low. High job demands can be associated with intense pressure of work and by being subjected to tight deadlines. Job latitude can be measured by job decision at work on the individual level. Therefore, working respondents were asked how often they face tight deadlines, how often they have to work at fast pace and how often they can change their pace of work or the order of their tasks (Béjean and Sultan-Taïeb, 2005, Paoli and Merllié, 2000) on a five likert scale ranging from never to very often. Respondents who stated that they often or very often work at fast pace and/or face tight deadlines while simultaneously not being able to change the pace of the work or the order of the tasks were qualified as having job strain. Therefore, the corresponding variable (Strain) takes the value of 1 and 0 otherwise. Non-working respondents were assumed to have no job strain.

To measure work flexibility, we asked respondents if the working days and the working hours are inflexible, somewhat flexible or very flexible. Respondents that stated that either working days or working hours are inflexible were classified as having no job flexibility (NoFlex). Respondents not working were seen as having flexibility and were aggregated with those having flexibility. Respondents were also asked to evaluate the physical demands of their work on a seven likert scale from very, very light to very, very exerting (Akerstedta, et al., 2002). When respondents stated that the physical demands of their work are exerting or more, the variable (PhDem) was given a score of 1 and 0 
otherwise. Similarly, respondents were asked how often they have to stand or walk while at work on a seven likert scale ranging from never to always. When respondents stated that they have to walk or stand while at work often or more, the variable (Walk) was given a score of 1 and 0 otherwise.

To proxy respondents' efficiency in reading nutritional labels $(\mathrm{m})$, we followed Byrd-Bredbenner et al. (2000). Each consumer was shown a typical nutritional label. The labels were printed on a $11(\mathrm{~cm}) \times 7(\mathrm{~cm})$ white paperboard and were formatted using the "Big 8” format (i.e., showing the amount of 8 key nutrients: energy, protein, carbohydrates, fat, sugar, saturated fat, fibre and sodium). The consumers were then asked a series of six questions. The first three questions tested their ability to locate quantitative information from the label. In each of the three questions, respondents were therefore asked: how much total carbohydrates, proteins and saturated fat, respectively, are in 100 grams of this food. The next two questions tested consumers' ability to calculate quantitative information, used to evaluate their diet planning computational ability. Participants were asked: if you ate 500 grams of this food, how much calories would you get? If you ate 200 grams of this food, how much fat would you get? The last question tested consumers' ability to choose between foods. A new label was shown to them using the same format with the previous label and consumers were then asked to indicate the healthiest food choice. For each correct answer, consumers were assigned a score of 1 and for each wrong answer they were assigned a score of 0 , thus yielding a score between 0 and 6 for each consumer (Effic). About 80.9\%, 84\% and 71.9\% of the respondents were able to correctly locate the requested quantitative information from the label with regards to carbohydrates, proteins and saturated fat, respectively (Table 4). The percentages dropped to $47.2 \%$ and $44.7 \%$ when consumers were asked to manipulate quantitative information in the next two questions, respectively. Finally, about $84.3 \%$ of the respondents were able to choose correctly between the two food alternatives based on the nutritional information showed to them.

The descriptive statistics of the dependent and independent variables are exhibited in Table 4. As in any survey, these variables are obviously self-reported and are hence subjective in nature and have limitations.

Table 4. Names and Description of independent variables

\begin{tabular}{llcccc}
\hline Variable & \multicolumn{1}{c}{ Variable Description } & Scale & N & Mean & S.D. \\
\hline \multirow{6}{*}{ NKnow } & Nutrition knowledge & $0-9$ & & 5.503 & 1.310 \\
& Experts advice $^{*}$ & 0,1 & 170 & 0.478 & 0.500 \\
& Food source $_{1}$ & 0,1 & 159 & 0.447 & 0.498 \\
& Food source $_{2}$ & 0,1 & 69 & 0.194 & 0.396 \\
& Food source $_{3}$ & 0,1 & 13 & 0.037 & 0.188 \\
& Food choice $_{1}$ & 0,1 & 272 & 0.764 & 0.425 \\
& Food choice $_{2}$ & 0,1 & 260 & 0.730 & 0.444 \\
& Dietary recommendation $_{1}$ & 0,1 & 318 & 0.893 & 0.309 \\
& Dietary recommendation $_{2}$ & 0,1 & 344 & 0.966 & 0.181 \\
& Dietary recommendation $_{3}$ & 0,1 & 354 & 0.994 & 0.075 \\
\hline \multirow{2}{*}{ Strain } & Respondent suffers from strain $=1$, & 0,1 & 25 & \multirow{2}{*}{0.073} & 0.261 \\
\hline & Otherwise=0 & & & & \\
\hline
\end{tabular}




\begin{tabular}{|c|c|c|c|c|c|}
\hline NoFlex & $\begin{array}{l}\text { Respondent has no workday or work } \\
\text { hour flexibility }=1 \text {, Otherwise }=0\end{array}$ & 0,1 & 71 & 0.199 & 0.400 \\
\hline PhDem & $\begin{array}{l}\text { Respondent's job is physical } \\
\text { demanding }=1 \text {, Otherwise }=0\end{array}$ & 0,1 & 43 & 0.121 & 0.326 \\
\hline Walk & $\begin{array}{l}\text { Respondent has to walk or stand often } \\
\text { while working }=1 \text {, Otherwise }=0\end{array}$ & 0,1 & 77 & 0.216 & 0.412 \\
\hline \multirow{7}{*}{ Effic } & Efficiency reading nutritional labels & $0-1$ & & 0.688 & 0.308 \\
\hline & Locate information $_{1}$ & 0,1 & 288 & 0.809 & 0.394 \\
\hline & Locate information $_{2}$ & 0,1 & 299 & 0.840 & 0.367 \\
\hline & Locate information $_{3}$ & 0,1 & 256 & 0.719 & 0.450 \\
\hline & Manipulate information $_{1}$ & 0,1 & 168 & 0.472 & 0.500 \\
\hline & Manipulate information $_{2}$ & 0,1 & 159 & 0.447 & 0.498 \\
\hline & Choose between foods & & 300 & 0.843 & 0.365 \\
\hline Planner & $\begin{array}{l}\text { Respondent is the major meal } \\
\text { planner }=1 \text {, Otherwise }=0\end{array}$ & 0,1 & 264 & 0.742 & 0.438 \\
\hline Workh & Work hours of a typical week & & & 18.465 & 21.735 \\
\hline Smoke & Respondent smokes $=1$, Otherwise $=0$ & 0,1 & 142 & 0.399 & 0.490 \\
\hline Gend & Respondent is male $=1$, Otherwise $=0$ & 0,1 & 130 & 0.365 & 0.482 \\
\hline Age & Respondent's age & & & 49.770 & 14.866 \\
\hline Hsize & Household size & & & 2.933 & 1.161 \\
\hline$E{ }^{\prime} c_{1}{ }^{*}$ & $\begin{array}{l}\text { Respondent has up to junior high } \\
\text { school education }=1 \text {, Else }=0\end{array}$ & 0,1 & 85 & 0.239 & 0.427 \\
\hline $\mathrm{Educ}_{2}$ & $\begin{array}{l}\text { Respondent has high school } \\
\text { education }=1 \text {, Else }=0\end{array}$ & 0,1 & 155 & 0.435 & 0.496 \\
\hline $\mathrm{Educ}_{3}$ & $\begin{array}{l}\text { Respondent has university education } \\
\text { or higher }=1 \text {, Else }=0\end{array}$ & & 116 & 0.326 & 0.469 \\
\hline $\operatorname{Inc}_{1}$ & $\begin{array}{l}\text { Annual household income is } \\
<€ 10.000=1 \text {, Else }=0\end{array}$ & 0,1 & 72 & 0.202 & 0.402 \\
\hline $\mathrm{Inc}_{2}$ & $\begin{array}{l}\text { Annual household income is } € 10.000 \text { - } \\
20.000=1 \text {, Else }=0\end{array}$ & 0,1 & 126 & 0.354 & 0.479 \\
\hline $\mathrm{Inc}_{3}$ & $\begin{array}{l}\text { Annual household income is } € 20.000 \text { - } \\
40.000=1 \text {, Else }=0\end{array}$ & 0,1 & 123 & 0.346 & 0.476 \\
\hline $\mathrm{Inc}_{4} *$ & $\begin{array}{l}\text { Annual household income is } \\
>€ 40.000=1 \text {, Else }=0\end{array}$ & 0,1 & 35 & 0.098 & 0.298 \\
\hline West & $\begin{array}{l}\text { Respondent resides west of the city of } \\
\text { Athens }=1 \text {, Else }=0\end{array}$ & 0,1 & 88 & 0.247 & 0.432 \\
\hline East & $\begin{array}{l}\text { Respondent resides east of the city of } \\
\text { Athens }=1 \text {, Else }=0\end{array}$ & 0,1 & 40 & 0.112 & 0.316 \\
\hline South & $\begin{array}{l}\text { Respondent resides south of the city } \\
\text { of Athens }=1 \text {, Else }=0\end{array}$ & 0,1 & 75 & 0.211 & 0.408 \\
\hline North & $\begin{array}{l}\text { Respondent resides north of the city } \\
\text { of Athens }=1 \text {, Else }=0\end{array}$ & 0,1 & 73 & 0.205 & 0.404 \\
\hline Center* & $\begin{array}{l}\text { Respondent resides in the center of } \\
\text { the city of Athens }=1 \text {, Else }=0\end{array}$ & 0,1 & 80 & 0.225 & 0.418 \\
\hline
\end{tabular}




\begin{tabular}{llllll}
\hline Exercise & $\begin{array}{l}\text { Respondent exercises for at least 30 } \\
\text { minutes at least once a week }\end{array}$ & 0,1 & 106 & 0.298 & 0.458 \\
\hline ISfrien & $\begin{array}{l}\text { Main nutrition information source is } \\
\text { friends/relatives=1, Else=0 }\end{array}$ & 0,1 & 68 & 0.191 & 0.394 \\
\hline ISmedia & $\begin{array}{l}\text { Main nutrition information source is } \\
\text { media=1, Else=0 }\end{array}$ & 0,1 & 172 & 0.517 & 0.500 \\
\hline ISmedical & $\begin{array}{l}\text { Main nutrition information source is } \\
\text { doctor/nutritionist=1, Else=0 }\end{array}$ & 0,1 & 30 & 0.084 & 0.278 \\
\hline ISelse & $\begin{array}{l}\text { Main nutrition information source is } \\
\text { something else=1, Else=0 }\end{array}$ & 0,1 & 12 & 0.034 & 0.181 \\
\hline ISno & $\begin{array}{l}\text { No main nutrition information } \\
\text { source=1, Else=0 }\end{array}$ & 0,1 & 62 & 0.174 & 0.380 \\
\hline
\end{tabular}

*The variables with an asterisk where omitted for estimation purposes

\subsection{ECONOMETRIC MODELLING}

The system of equations (17)-(20) has a clearly recursive form. One could then as well estimate the system equation-by-equation. However, there are efficiency gains by estimating the model simultaneously. The challenge of the system is that it involves two ordinal dependent variables (equations (17) and (20)) and two continuous dependent variables (equations (18) and (19)).

To estimate the system of equations we use the conditional mixed process estimator/CMP (Roodman, 2008). "Mixed process" means that different equations can have different kinds of dependent variables. "Conditional" stands for the fact that CMP maximizes a conditional likelihood function; the likelihood is decomposed into two components using Bayes's Law. The first for the continuous observations (OLS) and the second, conditional on the first, for the ordered ones (ordered probit). More precisely, for each observation, the likelihood for the errors in the equations for which the observation is "continuous" are modeled as jointly normally distributed. Then, for the observations that are ordered, their predicted values have the joint cumulative normal likelihood conditional on the errors for the continuous equations.

CMP is appropriate in the case where there is simultaneity, but instruments allow the construction of a recursive set of equations, as in two-stage least squares (2SLS), that can be used to consistently estimate structural parameters in the final stage. In this case CMP is a limited-information (LIML) estimator, and only the final stage's coefficients are structural, the rest being reduced-form parameters. What matters for the validity of cmp is that the system of equations is recursive, whether or not the model is.

The 2SLS analogy provides a lot of intuition here. Our model is an IV-type model, therefore the estimates are not efficient, just as 2SLS is inefficient relative to OLS. The coefficients are however consistent. The coefficients should be relatively unbiased, but not perfectly so, because in finite samples, even valid instruments are always somewhat empirically correlated with the error (empirical correlation coefficients are rarely exactly 0 ). In 2SLS, the bias becomes serious when instruments are weak. The same principles apply here. 


\section{RESULTS AND FINDINGS}

Results are presented in Table 5. Marginal effects and discrete changes are reported. Standard errors are robust to arbitrary forms of heteroskedasticity.

\subsection{LABEL USE EQUATION}

Results from the label use equation show that both nutrition knowledge (NKnow) and efficiency of reading nutritional labels (Effic) positively affect the probability of reading nutritional information from food labels. For example, a 1 point $(16.6 \%)$ increase in the efficiency of reading labels increases the probability of often reading labels by $2.5 \%$. Ditto, a one-point increase in nutrition knowledge increases the probability of often reading nutrition information by $3.5 \%$.

Geographical location effects also seem to affect label usage behaviour. Residents of the north part of the city, for example, are less likely to read nutrition information. In addition, consistent with past research findings (Drichoutis, et al., 2005, Govindasamy and Italia, 1999, Guthrie, et al., 1995, Kim, et al., 2001), males are less likely to read nutritional labels. More specifically, males are $15.7 \%$ less likely to often read on-pack nutrition information than females. Finally, regarding the work related characteristics we find that having no job flexibility positively affects the likelihood of searching for nutrient information.

The age variable has the correct signs and is consistent with Proposition 1 of the theoretical model, but is not statistically significant. Since, the empirical literature has not reached a consensus on the effect of age on label use (i.e. some studies find a negative effect e.g. (Cole and Balasubramanian, 1993, Kim, et al., 2001, 2001) while others find a positive effect (Coulson, 2000, Drichoutis, et al., 2005, Govindasamy and Italia, 1999)), it is an advantage of the model that it points theoretically to one direction and that this is verified by our empirical exercise.

\subsection{NUTRITION INFORMATION STOCK EQUATION}

Consistent with the hypothesized link of the theoretical model, we find that label usage behaviour can and will increase the stock of nutrition information. In addition, knowledge about general principles of nutrition as expressed by the nutrition knowledge measure (NKnow) facilitates acquisition of the specific nutrition information knowledge (nutrition information stock). Ditto, respondents with higher efficiency in reading nutrition information from food labels exhibit higher stock of nutrition information.

It is very interesting that the nutrition information sources variables, which are aimed to capture effects from external sources of information do not have a statistically significant effect. This may provide additional support to our intention to model the specific nutrition information knowledge (nutrition information stock) as a function of label usage behaviour. It appears that specific nutrition knowledge is predominantly formed by label usage behavior and not other external information sources. The effect of other variables, like age and education are consistent with prior expectations. For example, it is highly likely that older respondents exhibit higher stocks of nutrition information due to greater market experience.

\subsection{DIET QUALITY EQUATION (MEDITERRANEAN DIET)}

Results from Table 5 show that older and/or male individuals exhibit higher adherence to the Mediterranean diet i.e. have better diet quality. This may show that older individuals 
are trying to offset the deterioration in their health caused by aging by consuming healthier foods as represented by the higher adherence to the traditional Mediterranean diet. Smokers, on the other hand, exhibit lower adherence to the Mediterranean diet.

However, we find no statistically significant effect of nutrition information stock on diet quality.

\subsection{HEALTH STOCK EQUATION}

As exhibited in Table 5 diet quality positively affects health status. However, nutrition information stock has no effect on health.

In addition, males and older individuals are less likely to perceive their health status as good or very good.

Table 5. Results from conditional mixed process estimation (marginal effects and discrete changes)

\begin{tabular}{|c|c|c|c|c|c|c|c|c|c|c|}
\hline & \multicolumn{5}{|c|}{ Label use } & \multirow[t]{2}{*}{$\begin{array}{c}\text { Nutrition } \\
\text { information } \\
\text { stock }\end{array}$} & \multirow{2}{*}{$\begin{array}{c}\text { Diet } \\
\text { quality } \\
\text { index }\end{array}$} & \multicolumn{3}{|c|}{ Health } \\
\hline & Never & $\begin{array}{l}\text { Not } \\
\text { often }\end{array}$ & Medium & Often & Always & & & $\begin{array}{c}\text { Medium } \\
\text { or } \\
\text { worse }\end{array}$ & Good & $\begin{array}{l}\text { Very } \\
\text { good }\end{array}$ \\
\hline LabelUse & - & - & - & - & - & $\begin{array}{c}0.535 * * \\
(0.265)\end{array}$ & - & - & - & \\
\hline$G B$ & - & - & - & - & - & - & - & $\begin{array}{c}- \\
0.209 * * \\
(0.065)\end{array}$ & $\begin{array}{c}0.209 * * \\
(0.065)\end{array}$ & $\begin{array}{c}0.176 \\
(0.114)\end{array}$ \\
\hline $\mathrm{Ni}$ & - & - & - & - & - & - & $\begin{array}{c}-0.076 \\
(0.233)\end{array}$ & $\begin{array}{l}-0.067 \\
(0.075)\end{array}$ & $\begin{array}{c}0.067 \\
(0.075)\end{array}$ & $\begin{array}{c}0.056 \\
(0.054)\end{array}$ \\
\hline North & $\begin{array}{l}0.136 * \\
(0.073)\end{array}$ & $\begin{array}{c}0.005 \\
(0.005)\end{array}$ & $\begin{array}{l}-0.015 \\
(0.010)\end{array}$ & $\begin{array}{c}-0.126 * * \\
(0.061)\end{array}$ & $\begin{array}{c}-0.051 * * \\
(0.024)\end{array}$ & $\begin{array}{c}0.200 \\
(0.221)\end{array}$ & $\begin{array}{c}-0.193 \\
(0.280)\end{array}$ & $\begin{array}{c}0.003 \\
(0.085)\end{array}$ & $\begin{array}{c}-0.003 \\
(0.085)\end{array}$ & $\begin{array}{l}-0.003 \\
(0.071)\end{array}$ \\
\hline South & $\begin{array}{l}-0.065 \\
(0.063)\end{array}$ & $\begin{array}{l}-0.009 \\
(0.011)\end{array}$ & $\begin{array}{c}0.005 \\
(0.004)\end{array}$ & $\begin{array}{c}0.070 \\
(0.070)\end{array}$ & $\begin{array}{c}0.032 \\
(0.034)\end{array}$ & $\begin{array}{c}-0.139 \\
(0.221)\end{array}$ & $\begin{array}{c}0.295 \\
(0.273) \\
-\end{array}$ & $\begin{array}{c}0.082 \\
(0.067)\end{array}$ & $\begin{array}{c}-0.082 \\
(0.067)\end{array}$ & $\begin{array}{l}-0.066 \\
(0.055)\end{array}$ \\
\hline West & $\begin{array}{c}0.109 \\
(0.072)\end{array}$ & $\begin{array}{c}0.006 \\
(0.004)\end{array}$ & $\begin{array}{l}-0.011 \\
(0.009)\end{array}$ & $\begin{array}{c}-0.104 \\
(0.064)\end{array}$ & $\begin{array}{c}-0.043 * \\
(0.026)\end{array}$ & $\begin{array}{c}0.135 \\
(0.208)\end{array}$ & $\begin{array}{c}0.887 * * \\
(0.279)\end{array}$ & $\begin{array}{c}-0.147 \\
(0.112)\end{array}$ & $\begin{array}{c}0.147 \\
(0.112)\end{array}$ & $\begin{array}{c}0.133 \\
(0.138)\end{array}$ \\
\hline East & $\begin{array}{l}-0.083 \\
(0.069)\end{array}$ & $\begin{array}{l}-0.013 \\
(0.015)\end{array}$ & $\begin{array}{l}0.005 * \\
(0.003)\end{array}$ & $\begin{array}{c}0.091 \\
(0.082)\end{array}$ & $\begin{array}{c}0.044 \\
(0.043)\end{array}$ & $\begin{array}{l}-0.168 \\
(0.249)\end{array}$ & $\begin{array}{c}-0.251 \\
(0.322)\end{array}$ & $\begin{array}{l}-0.045 \\
(0.084)\end{array}$ & $\begin{array}{c}0.045 \\
(0.084) \\
-\end{array}$ & $\begin{array}{c}0.039 \\
(0.082)\end{array}$ \\
\hline Gend & $\begin{array}{c}0.163 * * \\
(0.053)\end{array}$ & $\begin{array}{l}0.010 * \\
(0.006)\end{array}$ & $\begin{array}{c}-0.016 * * \\
(0.007)\end{array}$ & $\begin{array}{c}-0.157 * * \\
(0.048)\end{array}$ & $\begin{array}{c}-0.067 * * \\
(0.020)\end{array}$ & $\begin{array}{c}-0.091 \\
(0.175)\end{array}$ & $\begin{array}{l}0.498 * \\
(0.268)\end{array}$ & $\begin{array}{c}0.142 * * \\
(0.072)\end{array}$ & $\begin{array}{c}0.142 * * \\
(0.072) \\
-\end{array}$ & $\begin{array}{l}-0.115 \\
(0.088)\end{array}$ \\
\hline Age & $\begin{array}{c}0.003 \\
(0.002)\end{array}$ & $\begin{array}{c}0.0003 \\
(0.0002)\end{array}$ & $\begin{array}{l}-0.0002 \\
(0.0002)\end{array}$ & $\begin{array}{l}-0.003 \\
(0.002)\end{array}$ & $\begin{array}{l}-0.001 \\
(0.001)\end{array}$ & $\begin{array}{c}0.021 * * \\
(0.006)\end{array}$ & $\begin{array}{c}0.027 * * \\
(0.007)\end{array}$ & $\begin{array}{c}0.007 * * \\
(0.002)\end{array}$ & $\begin{array}{c}0.007 * * \\
(0.002)\end{array}$ & $\begin{array}{l}-0.005 \\
(0.003)\end{array}$ \\
\hline Hsize & $\begin{array}{l}-0.016 \\
(0.021)\end{array}$ & $\begin{array}{c}-0.002 \\
(0.002)\end{array}$ & $\begin{array}{c}0.001 \\
(0.002)\end{array}$ & $\begin{array}{c}0.016 \\
(0.021)\end{array}$ & $\begin{array}{c}0.007 \\
(0.010)\end{array}$ & $\begin{array}{c}0.060 \\
(0.063)\end{array}$ & $\begin{array}{c}-0.014 \\
(0.090)\end{array}$ & $\begin{array}{l}-0.023 \\
(0.028)\end{array}$ & $\begin{array}{c}0.023 \\
(0.028)\end{array}$ & $\begin{array}{c}0.019 \\
(0.020)\end{array}$ \\
\hline
\end{tabular}




\begin{tabular}{|c|c|c|c|c|c|c|c|c|c|c|}
\hline$E_{\text {duc }}$ & $\begin{array}{l}-0.032 \\
(0.057)\end{array}$ & $\begin{array}{l}-0.003 \\
(0.006)\end{array}$ & $\begin{array}{c}0.003 \\
(0.005)\end{array}$ & $\begin{array}{c}0.032 \\
(0.059)\end{array}$ & $\begin{array}{c}0.014 \\
(0.027)\end{array}$ & $\begin{array}{l}0.429 * * \\
(0.175)\end{array}$ & $\begin{array}{l}-0.101 \\
(0.256)\end{array}$ & $\begin{array}{l}-0.082 \\
(0.088)\end{array}$ & $\begin{array}{c}0.082 \\
(0.088)\end{array}$ & $\begin{array}{c}0.069 \\
(0.064)\end{array}$ \\
\hline $\mathrm{Educ}_{3}$ & $\begin{array}{l}-0.080 \\
(0.071)\end{array}$ & $\begin{array}{l}-0.010 \\
(0.011)\end{array}$ & $\begin{array}{c}0.006 \\
(0.005)\end{array}$ & $\begin{array}{c}0.084 \\
(0.077)\end{array}$ & $\begin{array}{c}0.039 \\
(0.038)\end{array}$ & $\begin{array}{l}0.427^{*} \\
(0.242)\end{array}$ & $\begin{array}{l}-0.065 \\
(0.378)\end{array}$ & $\begin{array}{l}-0.084 \\
(0.109)\end{array}$ & $\begin{array}{c}0.084 \\
(0.109)\end{array}$ & $\begin{array}{c}0.073 \\
(0.089)\end{array}$ \\
\hline $\mathrm{Inc}_{2}$ & $\begin{array}{c}0.017 \\
(0.067)\end{array}$ & $\begin{array}{c}0.002 \\
(0.006)\end{array}$ & $\begin{array}{l}-0.002 \\
(0.006)\end{array}$ & $\begin{array}{l}-0.017 \\
(0.067)\end{array}$ & $\begin{array}{l}-0.008 \\
(0.029)\end{array}$ & $\begin{array}{c}0.050 \\
(0.182)\end{array}$ & $\begin{array}{c}0.071 \\
(0.265)\end{array}$ & $\begin{array}{c}0.023 \\
(0.069)\end{array}$ & $\begin{array}{l}-0.023 \\
(0.069)\end{array}$ & $\begin{array}{l}-0.019 \\
(0.059)\end{array}$ \\
\hline $\mathrm{Inc}_{3}$ & $\begin{array}{c}0.004 \\
(0.074)\end{array}$ & $\begin{array}{l}0.0004 \\
(0.007)\end{array}$ & $\begin{array}{l}-0.0003 \\
(0.006)\end{array}$ & $\begin{array}{l}-0.004 \\
(0.075)\end{array}$ & $\begin{array}{l}-0.002 \\
(0.033)\end{array}$ & $\begin{array}{l}-0.008 \\
(0.210)\end{array}$ & $\begin{array}{c}0.304 \\
(0.293)\end{array}$ & $\begin{array}{c}0.033 \\
(0.095)\end{array}$ & $\begin{array}{l}-0.033 \\
(0.095)\end{array}$ & $\begin{array}{l}-0.027 \\
(0.085)\end{array}$ \\
\hline $\mathrm{Inc}_{4}$ & $\begin{array}{c}0.080 \\
(0.114)\end{array}$ & $\begin{array}{c}0.004 \\
(0.003) \\
-\end{array}$ & $\begin{array}{c}-0.009 \\
(0.015)\end{array}$ & $\begin{array}{c}-0.075 \\
(0.100)\end{array}$ & $\begin{array}{l}-0.031 \\
(0.038)\end{array}$ & $\begin{array}{c}0.226 \\
(0.289)\end{array}$ & $\begin{array}{c}0.148 \\
(0.447)\end{array}$ & $\begin{array}{c}0.032 \\
(0.107)\end{array}$ & $\begin{array}{l}-0.032 \\
(0.107)\end{array}$ & $\begin{array}{l}-0.026 \\
(0.088)\end{array}$ \\
\hline Workh & $\begin{array}{l}-0.001 \\
(0.001)\end{array}$ & $\begin{array}{c}0.00005 \\
(0.0001)\end{array}$ & $\begin{array}{c}0.00004 \\
(0.0001)\end{array}$ & $\begin{array}{c}0.001 \\
(0.001)\end{array}$ & $\begin{array}{l}0.0002 \\
(0.001)\end{array}$ & - & - & $\begin{array}{l}-0.001 \\
(0.002)\end{array}$ & $\begin{array}{c}0.001 \\
(0.002)\end{array}$ & $\begin{array}{c}0.001 \\
(0.001)\end{array}$ \\
\hline Strain & $\begin{array}{l}-0.061 \\
(0.059)\end{array}$ & $\begin{array}{l}-0.009 \\
(0.012)\end{array}$ & $\begin{array}{c}0.004 \\
(0.003)\end{array}$ & $\begin{array}{c}0.066 \\
(0.068)\end{array}$ & $\begin{array}{c}0.032 \\
(0.035)\end{array}$ & - & - & $\begin{array}{c}0.036 \\
(0.064)\end{array}$ & $\begin{array}{l}-0.036 \\
(0.064)\end{array}$ & $\begin{array}{l}-0.029 \\
(0.045)\end{array}$ \\
\hline NoFlex & $\begin{array}{l}-0.089 \% \\
(0.049)\end{array}$ & $\begin{array}{l}-0.013 \\
(0.010)\end{array}$ & $\begin{array}{c}0.006 * * \\
(0.003)\end{array}$ & $\begin{array}{l}0.096^{*} \\
(0.057)\end{array}$ & $\begin{array}{c}0.046 \\
(0.030)\end{array}$ & - & - & $\begin{array}{c}0.048 \\
(0.058)\end{array}$ & $\begin{array}{l}-0.048 \\
(0.058)\end{array}$ & $\begin{array}{l}-0.039 \\
(0.035)\end{array}$ \\
\hline PhDem & $\begin{array}{l}-0.021 \\
(0.094)\end{array}$ & $\begin{array}{l}-0.002 \\
(0.012)\end{array}$ & $\begin{array}{c}0.002 \\
(0.007)\end{array}$ & $\begin{array}{c}0.022 \\
(0.099)\end{array}$ & $\begin{array}{c}0.010 \\
(0.046)\end{array}$ & - & - & $\begin{array}{c}0.043 \\
(0.057)\end{array}$ & $\begin{array}{l}-0.043 \\
(0.057)\end{array}$ & $\begin{array}{l}-0.035 \\
(0.036)\end{array}$ \\
\hline Walk & $\begin{array}{c}0.053 \\
(0.065) \\
-\end{array}$ & $\begin{array}{c}0.004 \\
(0.004)\end{array}$ & $\begin{array}{c}-0.005 \\
(0.007)\end{array}$ & $\begin{array}{c}-0.052 \\
(0.061)\end{array}$ & $\begin{array}{c}-0.022 \\
(0.025)\end{array}$ & - & - & $\begin{array}{l}-0.036 \\
(0.044)\end{array}$ & $\begin{array}{c}0.036 \\
(0.044)\end{array}$ & $\begin{array}{c}0.030 \\
(0.033)\end{array}$ \\
\hline NKnow & $\begin{array}{c}0.034^{* * *} \\
(0.016)\end{array}$ & $\begin{array}{c}-0.003 \\
(0.002)\end{array}$ & $\begin{array}{l}0.003^{*} \\
(0.002)\end{array}$ & $\begin{array}{l}0.035 * * \\
(0.017)\end{array}$ & $\begin{array}{l}0.015^{* *} \\
(0.008)\end{array}$ & $\begin{array}{c}0.166 * * \\
(0.056)\end{array}$ & - & - & - & - \\
\hline Effic & $\begin{array}{l}-0.025^{*} \\
(0.013)\end{array}$ & $\begin{array}{l}-0.002 \\
(0.002)\end{array}$ & $\begin{array}{c}0.002 \\
(0.001)\end{array}$ & $\begin{array}{l}0.025^{*} \\
(0.013)\end{array}$ & $\begin{array}{l}0.011^{*} \\
(0.006)\end{array}$ & $\begin{array}{l}0.155^{* * *} \\
(0.045)\end{array}$ & - & - & - & - \\
\hline Taste & $\begin{array}{c}0.010 \\
(0.039)\end{array}$ & $\begin{array}{c}0.001 \\
(0.004)\end{array}$ & $\begin{array}{l}-0.001 \\
(0.003)\end{array}$ & $\begin{array}{l}-0.011 \\
(0.040)\end{array}$ & $\begin{array}{l}-0.005 \\
(0.018)\end{array}$ & 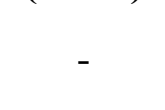 & $\begin{array}{c}0.171 \\
(0.252)\end{array}$ & - & - & - \\
\hline ISelse & - & - & 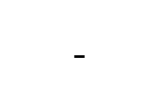 & - & - & $\begin{array}{c}0.535^{* *} \\
(0.265)\end{array}$ & - & - & - & - \\
\hline ISfrien & - & - & - & - & - & $\begin{array}{c}0.303 \\
(0.291)\end{array}$ & - & - & - & - \\
\hline ISmedia & - & - & - & - & - & $\begin{array}{c}0.040 \\
(0.199)\end{array}$ & - & - & - & - \\
\hline ISmedical & - & - & - & - & - & $\begin{array}{c}0.130 \\
(0.178)\end{array}$ & - & - & - & - \\
\hline Smoke & - & - & - & - & - & - & $\begin{array}{l}-0.363^{*} \\
(0.195)\end{array}$ & $\begin{array}{l}-0.027 \\
(0.087)\end{array}$ & $\begin{array}{c}0.027 \\
(0.087)\end{array}$ & $\begin{array}{c}0.023 \\
(0.079)\end{array}$ \\
\hline Planner & - & - & - & - & - & - & $\begin{array}{l}-0.270 \\
(0.218)\end{array}$ & - & - & - \\
\hline Exercise & - & - & - & - & - & - & - & $\begin{array}{l}-0.014 \\
(0.016)\end{array}$ & $\begin{array}{c}0.014 \\
(0.016)\end{array}$ & $\begin{array}{c}0.012 \\
(0.010)\end{array}$ \\
\hline $\begin{array}{l}\text { Log- } \\
\text { pseudolikelihood }\end{array}$ & & & & & & & & & & \\
\hline
\end{tabular}


$* *(*)$ Statistically significant at the $5 \%(10 \%)$ level.

Standard errors in parenthesis (robust standard errors to arbitrary forms of heteroskedasticity).

Sample size is 356 .

\section{DISCUSSION AND CONCLUSIONS}

The purpose of this paper was to analyze the economics of nutrition information search behaviour by using a formal utility theoretic model not only to fill the void in the literature that up to now has only used empirical approaches, but also because theory can sometimes provide insights that intuition overlooks. We therefore developed a simple model where the time someone might spend in searching for nutrition information was considered within the context of a time allocation decision. We also used comparative statics to test the predictions of the model under variations of some key exogenous variables.

Using the theoretical model as a guide, we then collected data from a large-scale survey conducted in Athens, Greece to empirically test the model. We approximated the time spent searching for nutrition information with time searching for on-pack nutrition information of food products. Based on the theoretical model, we estimated a system of simultaneous equation using the conditional mixed process estimator (Roodman, 2008). Results confirmed some of the hypothesized theoretical relations. For example, we found that efficiency in reading nutrition information can affect the probability of reading labels and that label usage behaviour can affect specific nutrition knowledge. However, we were not able to establish a link between specific nutrition knowledge and diet quality or health. While this finding may not be what we are expecting or hoping for, it is nevertheless a finding based on our empirical data which is limited to our area of study, Athens, Greece. Future studies should replicate our empirical study in other countries or regions to test the robustness of this finding and/or the definitive reasons behind the finding. We did find however that diet quality positively affects perceived health status.

The regulatory environment in some countries (e.g., US) has long recognized the possibility that providing mandatory nutritional information on food products may help consumers make healthier food choices and therefore, help reduce diet-related diseases. In EU countries, the debate has been launched when in January 2003, the Commission consulted Member States and stakeholders about the revision of the current regulation (90/496 EOC) and the preparation of a proposal amending, among others, the voluntary provision of nutritional information to become mandatory. This debate is based on the view that provision of nutritional information will increase time spent searching for nutrition information but more importantly that it will have an effect on consumers' health. However, based on our empirical modelling which follows from the theoretical model we cannot confirm that label use and nutrition knowledge will have an effect on either diet quality or health. This finding would imply that it might not be worth spending a lot of time, resources, and effort in developing a mandatory nutritional labelling program if indeed nutritional information does not help consumers improve the quality of their diets and their health. However, as mentioned above, more research is warranted to test the robustness of our empirical findings. We hope that the theoretical model presented here can be used as a guide or basis for future theoretical and empirical 
extensions that will shed more light on consumer behaviour related to nutrition information search. 


\section{REFERENCES}

"Obesity and Overweight." World Health Organization.

Ajzen, I., and M. Fishbein. Understanding Attitudes and Predicting Behavior: Englewoods Cliffs, NJ: Prentice Hall, 1980.

Akerstedta, T., et al. "Sleep disturbances, work stress and work hours: A cross-sectional study." Journal of Psychosomatic Research 53(2002): 741- 748.

Backman, D. R., et al. "Psychosocial predictors of healthful dietary behavior in adolescents." Journal of Nutrition Education and Behavior 34, no. 4(2002): 184193.

Bandura, A. Social foundations of thought and action: A social cognitive theory: Prentice-Hall (Englewood Cliffs, N.J.) 1986.

Becker, G. (2002) The age of human capital, ed. E. P. Lazear, Hoover Press, pp. 3-8.

Becker, G. "A theory of the allocation of time." The Economic Journal 75, no. 299(1965): 493-517.

Becker, M. H. (1974) The health belief model and personal health behavior, vol. 2.

Béjean, S., and H. Sultan-Taïeb. "Modeling the economic burden of diseases imputable to stress at work." European Journal of Health Economics 50(2005): 16-23.

Bissonnette, M. M., and I. R. Contento. "Adolescents' perspectives and food choice behaviors in terms of the environmental impacts of food production practices: Application of a psychosocial model." Journal of nutrition education 33, no. 2(2001): 72-82.

Blaylock, J., et al. "Economics, food choices, and nutrition." Food Policy 24(1999): 269286.

Byrd-Bredbenner, C., A. Wong, and P. Cottee. "Consumer understanding of US and EU nutrition labels." British Food Journal 102, no. 8(2000): 615-629.

Caswell, J. A., and D. I. Padberg. "Toward a more comprehensive theory of food labels." American Journal of Agricultural Economics 74, no. 2(1992): 460-468.

Chern, W. S., and K. Rickertsen (2003) Health, nutrition and food demand, CABI publishing.

Cohen, S., and G. M. Williamson. "Stress and infectious disease in humans." Psychological Bulletin 109, no. 1(1991): 5-24.

Cole, C. A., and S. K. Balasubramanian. "Age differences in consumers' search for information: Public policy implications." The Journal of Consumer Research 20, no. 1(1993): 157-169.

Collings, J. J. "The valuation of leisure travel time." Regional and Urban Economics 4, no. 1(1974): 65-67.

Coulson, N. S. "An application of the stages of change model to consumer use of food labels." British Food Journal 102, no. 9(2000): 661-668.

Dahlgren, G., and M. Whitehead. "Policies and strategies to promote social equity in health." Stockholm: Institute of Future Studies (1991).

De Donnea, F. X. "Consumer behaviour, transport mode choice and value of time: Some micro-economic models." Regional and Urban Economics 1, no. 4(1972): 355382.

DeSerpa, A. "A theory of the economics of time." The Economic Journal 81, no. 324(1971): 828-846. 
Drichoutis, A. C., P. Lazaridis, and R. M. Nayga, Jr. "Nutrition knowledge and consumer use of nutritional food labels." European Review of Agricultural Economics 32, no. 1(2005): 93-118.

Evans, A. W. "On the theory of the valuation and allocation of time." Scottish Journal of Political Economy 19, no. 1(1972): 1-17.

Fischler, C. "Food, self and identity." Social Science Information 27, no. 2(1988): 275292.

Forster, M. "The meaning of death: Some numerical simulations of a model of healthy and unhealthy consumption." Journal of Health Economics 20, no. 4(2001): 613638.

Furst, T., et al. "Food choice: A conceptual model of the process." Appetite 26, no. 3(1996): 247-266.

Ganster, D. C., and J. Schaubroeck. "Work stress and employee health." Journal of Management 17, no. 2(1991): 235-271.

Gnardellis, C., et al. "Reproducibility and validity of an extensive semiquantitative food frequency questionnaire among Greek school teachers." Epidemiology 6, no. 1(1995): 74-77.

Govindasamy, R., and J. Italia. "The influence of consumer demographic characteristics on nutritional label usage." Journal of Food Products Marketing 5, no. 4(1999): 55-68.

Grossman, M. "The human capital model of the demand for health." National Bureau of Economic Research, Working Paper 7078: Cambridge, MA, USA (1999).

Grossman, M. "On the concept of health capital and the demand for health." The Journal of Political Economy 80, no. 2(1972): 223-255.

Guthrie, J. F., et al. "Who uses nutritional labeling, and what effects does label use have on diet quality?" Journal of Nutrition Education 27, no. 4(1995): 163-172.

Haskell, W. L. "Physical activity in the prevention and management of coronary heart disease." PCPFS Research Digest 2, no. 1(1995).

Heckman, J. J. "Shadow prices, market wages, and labor supply." Econometrica 42, no. 4(1974): 679-694.

John, D. R., and C. Cole. "Age differences in information processing: Understanding deficits in young and elderly consumers." The Journal of Consumer Research 13, no. 3(1986): 297-315.

Karasek, R. "Job demands, job decision latitude, and mental strain: Implications for job redesign." Administrative Science Quarterly 24(1979): 285-308.

Karasek, R., and L. Theorell. Health work stress, productivity and reconstruction of working life. New-York: Wiley, 1990.

Kim, S.-Y., R. M. Nayga, Jr., and O. Capps, Jr. "Food label use, self-selectivity, and diet quality." The Journal of Consumer Affairs 35, no. 2(2001): 346-363.

Kim, S.-Y., R. M. Nayga, Jr., and O. Capps, Jr. "Health knowledge and consumer use of nutritional labels: The issue revisited." Agricultural and Resource Economics Review 30, no. 1(2001): 10-19.

Lin, N., and W. M. Ensel. "Life stress and health: Stressors and resources." American Sociological Review 54, no. 3(1989): 382-399.

Maddux, J. E., and R. W. Rogers. "Protection motivation and self-efficacy: a revised theory of fear appeals and attitude change." Journal of Experimental Social Psychology 19, no. 5(1983): 469-479. 
Murcott, A. The nation's diet: The social science of food choice Longman, London, 1998.

Nayga, R. M., Jr. "Determinants of consumers' use of nutritional information on food packages." Journal of Agricultural and Applied Economics 28, no. 2(1996): 303312.

Nayga, R. M., Jr. "Nutrition knowledge, gender, and food label use." The Journal of Consumer Affairs 341(2000): 97-112.

Paoli, P., and D. Merllié. "Third European survey on working conditions 2000." European Foundation for the Improvement of Living and Working Conditions (2000).

Parmenter, K., and J. Wardle. "Development of a general nutrition knowledge questionnaire for adults." European Journal of Clinical Nutrition 53, no. 4(1999): 298-308.

Phillips, L. W., and B. Sternthal. "Age differences in information processing: A perspective on the aged consumer." Journal of Marketing Research 14(1977): 243-249.

Roodman, D. M. "CMP: Stata module to implement conditional (recursive) mixed process estimator." Downloadable from http://fmwww.bc.edu/repec/bocode/c/cmp.ado (2008).

Rosenkranz, R. R., and D. A. Dzewaltowski. "Model of the home food environment pertaining to childhood obesity." Nutrition Reviews 66, no. 3(2008): 123-140.

Samuelson, P. A. Foundations of Economic Analysis. Cambridge: Harvard University Press, 1947.

Silberberg, E. "A revision of comparative statics methodology in economics, or, how to do comparative statics on the back of an envelope." Journal of Economic Theory 7(1974): 159-172.

Silberberg, E., and W. Suen. The structure of economics, A mathematical approach. 3rd ed. New York: McGraw-Hill, 2001.

Sobal, J. (2004) Sociological analysis of the stigmatization of obesity, ed. J. Germov, and L. Williams, 2nd Edition, Oxford University Press Melbourne, Australia, pp. 383397.

Stigler, G. J. "The economics of information." The Journal of Political Economy 69, no. 3(1961): 213-225.

Szykman, L. R., P. N. Bloom, and A. S. Levy. "A proposed model of the use of package claims and nutrition labels." Journal of Public Policy \& Marketing 16, no. 2(1997): 228-241.

Tomlinson, M. "Lifestyle and Social Class." European Sociological Review 19, no. 1(2003): 97-111.

Trichopoulou, A., et al. "Adherence to a Mediterranean diet and survival in a Greek population." The New England Journal of Medicine 348, no. 26(2003): 25992608.

van der Horst, K., et al. "A systematic review of environmental correlates of obesityrelated dietary behaviors in youth." Health Education Research 22, no. 2(2007): 203-226.

Wagstaff, A. "The demand for health: An empirical reformulation of the Grossman model." Health Economics 2(1993): 189-198. 
Wickens, C. D., R. Braune, and A. Stokes. "Age differences in the speed and capacity of information processing: I. A dual-task approach." Psychology and Aging 2, no. 1(1987): 70-78.

Wilkins, K., and M. P. Beaudet. "Work stress and health." Health Reports 10, no. 3(1998): 47-62.

You, W., and R. M. Nayga, Jr. "Household fast food expenditures and children's television viewing: Can they really significantly influence children's dietary quality?" Journal of Agricultural and Resource Economics 30, no. 2(2005): 302314. 